\title{
ビタミンE久乏ラットのグルタチオン低下に伴う腎蔵障害と グルタチオンエステル投与による防御
}

\author{
萩 原 清 和*, 小 篠 栄** \\ 岡純 $* * *$, 市川富 夫* \\ * 国立健康 - 栄養研究所応用食品部 \\ ** 東京女子医科大学堅センター \\ *** 国立健康・栄篦研究所老人健康・栄養部
}

\author{
Kidney Injury Induced by GSH Depletion and Vitamin E Deficiency \\ in Rats and Prevention by GSH Ester Administration \\ Kiyokazu HAGIWARA,* Hisashi OZASA,** Jun OKA*** \\ and Tomio ICHIKAWA* \\ * Division of Applied Food Research, National Institute of Health \\ and Nutrition, Shinjuku-ku, Tokyo 162 \\ ** Kidney Center, Tokyo Women's Medical College, Shinjuku-ku, Tokyo 162 \\ *** Division of Geriatric Health Science, National Institute of Health \\ and Nutrition, Shinjuku-ku, Tokyo 162
}

\begin{abstract}
Nippon Eiyō Shokuryō Gakkaishi (J. Jpn. Soc. Nutr. Food Sci.) 45, 429 434 (1992)
Four-week-old male Wistar rats were fed a vitamin E (VE)-deficient diet for 8 weeks, followed by intraperitoneal injection of DL-buthionine- $[S, R]$-sulfoximine (BSO), an inhibitor of $\gamma$-glutamylcysteine synthetase, at $1 \mathrm{mmol} / \mathrm{kg}$ body weight. Rats in a glutathione (GSH) treatment group were intraperitoneally injected three times with GSH monoisopropyl ester at $1.7 \mathrm{mmol} / \mathrm{kg}$ body weight in addition to BSO administration. The TBA (2-thiobarbituric acid) value, GSH content, lipofuscin content and enzyme activities in the kidneys of rats, and BUN (blood urea nitrogen) content, creatinine content and LDH (lactate dehydrogenase) activity in their sera were measured. GSH depletion by BSO administration was accompanied by a decrease in the renal TBA value and a marked increase in the renal lipofuscin content. This increase in the renal lipofuscin content was prevented by GSH treatment. The increase in serum creatinine and the decrease in renal enzyme activities of rats administered BSO were inhibited by GSH treatment. GSH treatment did not completely prevent necrosis of the proximal renal tubule epithelia but such degeneration in rats treated with GSH was observed only in a narrow zone of the $\mathrm{S}_{3}$ segment near the descending thin limb of Henle's loop. It seems that lipid peroxides produced by VE deficiency may cause the accumulation of lipofuscin in the presence of renal GSH depletion, followed by necrosis of the proximal renal tubule epithelia. These results suggest that GSH has an important role in preventing the production of lipofuscin by reaction of lipid peroxides with amino acids.
\end{abstract}

Key Words kidney injury, lipid peroxidation, vitamin E deficiency, GSH depletion, GSH monoisopropyl ester.

(Received January 14, 1992)

ビタミンE (VE) は主要な生体内抗酸化㓮として知ら れ,クルタチオン (GSH) す生体内に最す多量に存在す るチオールとしてその抗酸化作用に興味がすたれてい

** 干162 東京都新宿区河田町 8-1

る。

無細胞画分における酵素的，非酵秉的過酸化に対する $\mathrm{VE}^{12 \sim 8)}$ ○ $\mathrm{GSH}^{4) ~ 6)}$ の過酸化脂質生成阻止能について は種々報告されている。一方，単離 VE久乏紐胞を用 い, その GSH 量を低下させると細胞崩壊が起こる。こ 
430

れはVE添加によって防御される7゙。た, VE久乏ラッ トの肝細胞壊死が食飳性含硫了ミノ酸の低下により著し く強められることが知られている8 。

Meister らは, L-buthionine- $[S, R]$-sulfoximine を 幼若マウスに投与し，GSH 低下に伴ら障害が骨格筋9， 肺 ${ }^{10)}$, 空腸や結腸11), 目の水晶体 ${ }^{122} て ゙$ 観察され, この障 害は GSH ester 誘導体の投与によって抑制あるいは防 御されることを報告している。

われわれは，GSH とVE の in vivo における協同の 役割を明らかにするため, VE 欠乏ラットに GSH 合成 阻害剤の DL-buthionine- $[S, R]$-sulfoximine (BSO) を 投与し GSH 含量を減少させたところ，堅臓のみが肥 大し, 他の䁍器にはこのような現象は観察されなかっ た13)。VE 欠乏ラットの GSH 低下に伴い, 冎葴肥大か; 観察されたことから，堅䁍におけける組織障害を推定し， 光学顕徽鏡による検索を行ったところ, 近位尿細管上皮 細胞壊死が惹起し, VE 欠乏と GSH 低下がこの腎䁍障

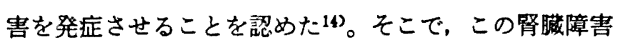
の発症機序解明のため, 経日的な検討を行ったところ, VE 欠乏時の過酸化脂質生成に伴いTBA 值が上昇し, BSO 投与後 GSH 量の低下により堅障害の診断に用いら れる指標が経日的に上昇するとともに, 経日的な TBA 値の低下を伴ってリポフスチン量が急激に増加した。こ れらのことから, 過酸化脂質からのリポフスチンの大量 生成とこれによる堅機能障害, さらに続いて近位尿細管 上皮細胞の壊死が惹起し，腎蔵障害が発症することを認 め,この腎䑏障害発症に GSH が深く関与することが示 㖫された15)。

Meister ら ${ }^{9) \sim 12)} は$, BSO 投与による GSH 低下に伴 う組籖障害が GSH ester 投与により抑制あるいは防御 できるとしていることから，本腎缄障害に対する GSH ester の効果を検討した。VE久乏ラットにBSOを1日 1 回 3 日間投与寸ることにより GSH を低下させ, 惹起 する焣臓障害に GSH monoisopropyl ester (GSH ester) を投与し，過酸化脂質からのリポフスチン生成抑制への GSH の関与, 婴機能低下や堅障害発症に関する GSH の 防御効果などについて検討したが，近位尿細管上皮細胞 のらち近位直尿細管 $\left(\mathrm{S}_{3}\right.$ 部位) の上皮細胞に広く壊死か 認められ，障害を完全には防御することはできなかった ことを報告した18)。

前報では BSO 投与条件が厳しすぎて, GSH esterの 効果が明瞭に現れなかったと考えられたので, 本研究で

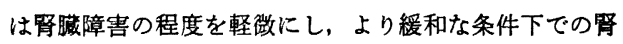
機能低下や罱障害発症に対する GSH の防御効果を検討 するため，BSO 投与を 1 回とし，さらに GSH ester の 投与回数を多くして研究を行った。

\section{日本栄㐮・食粗学会誌}

\section{実 験 方 法}

\section{1. 飼料}

油脂は市販サフラワー油（油蠟薬品(株)）を活性炭処 理して得た低 VEサフラワー油を使用した17)。VE 欠乏 飼料 (VE $0.52 \mathrm{IU} / \mathrm{kg}$ diet) の組成は次のようである。 カゼイン: $20 \%$ ，シュクロース:50\%，七ルロースパウ ダー: 5\%, ミネラル混合 ${ }^{18)}: 3.5 \%$, ビタミン混合 : 1 $\%$, 重酒石酸コリン: $0.2 \%$ 、コーンスターチ: $10.3 \%$, サフラワー油 : $10 \%$ 。ビタミン混合はVEを除き AIN76 組成 ${ }^{18)}$ に淛じて調製した。なお，サフラワー油の脂 肪酸組成はミリスチン酸: $1.5 \%$ ，ハルミチン酸: 7.2 $\%$,ステフリン酸: $2.6 \%$,オレイン酸: $12.2 \%$,リノー ル酸: $76.5 \%$ で,パルミトレイン酸およびリノレン酸 は検出されなかった。

\section{2. 实験助物および飼京方法}

4 週龄 Wistar 系雄性ラット（日本クレア(株))を上 記飼料で 8 週間飼育後 3 群に分けた。1 群にはBSO (シ グマ(株)) $1 \mathrm{mmol} / \mathrm{kg}$ 体重を 1 回腹腔内投与した (BSO 投与群)。他の 1 群は BSO 投与とともに，この投与の 1 時間前と 1 時間後， 3 時間後の 3 回，それぞれ GSH ester $1.7 \mathrm{mmol} / \mathrm{kg}$ 体重を腹腔内投与した（GSH 投与 群)。BSO や GSH ester などの処理を行わない群をこ ントロール群とした。飼料は毎日給餉し, 领料水ととも に自由摄取とした。

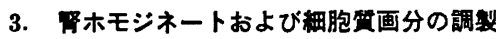

BSO 投与 5 時間後にェーテル麻酔下, 腹部大動脈よ

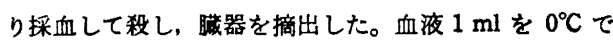
1 時間静置したのち，3,000 rpm，15 分間遠心分離し血 清を得た。各群の叒䐬は, 重量の 9 倍量の $1.15 \%$ 塩化 カリウム溶液でホモジナイズし、ホモジネートの一部は 2-チオバルビッール酸 (TBA) 值の測定に用いた。残り は $105,000 \times g ， 60$ 分間遠心分離し，得られる上清画分 を cytoplasm 画分として酵索活性の測定に用いた。

\section{4. 測定方法}

溶血反応はシアルル酸法で測定した ${ }^{18)}$ 。ニントロー ル群の溶血率は 95\%以上であった。年施ocopherol は

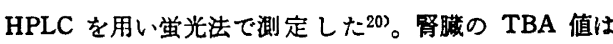
Aust の方法21), リボフスチン量は Fletcher の方法22) で測定した。総 GSH 量は Tietze 法 ${ }^{23)} て ゙$ 測定し、グル タチオンペルオキシダーゼ(GSH-px) 活性24およびグル タチオンリダクターゼ (GSSG-R) 活性 ${ }^{25)}$ は Burk の方 法を用い,クルタチオン S-トランスフェラーゼ（GST） 活性は 1-chloro-2,4-dinitrobenzene を基質に用い, Habig の方法20)で湘定した。タンバク量は Lowry 法に より測定した ${ }^{272}$ 。血液尿素空素（BUN）是はウレアーゼ インドフェノール法, クレアチニン量はヤッセ法,また 
乳酸脱水素酵素 (LDH) 活性はピルビン酸を基質に UV 法で，それぞれ日立自動分析装置 736 型を用い(株)三菱 油化ビーシーェルにて測定した。

各データは, Aspin-Welch test で検定を行った。

\section{実 験 結 果}

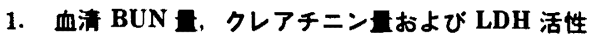
BSO 投与群の BUN 量, クレアチニン量扩よび LDH 活性はコントロール群に比べそれぞれ3.0，5.7，2.6 倍 と急激な上昇が認められた。これに対し，GSH 投与群 では BUN 量はコントロール群の 4.6 倍で BSO 投与群

Table 1. Effect of GSH monoester on BUN and creatinine contents and LDH activity in the sera of rats administered BSO.

\begin{tabular}{|c|c|c|c|}
\hline & Control & $\begin{array}{c}\text { Treated with } \\
\text { BSO }\end{array}$ & $\begin{array}{l}\text { Treated with } \\
\text { BSO and } \\
\text { GSH ester }\end{array}$ \\
\hline$\underset{(\mathrm{U} / l)}{\mathrm{LDH}}$ & $2210 \pm 220^{a)}$ & $\left.5800 \pm 1280^{a}\right)$ b) & $\left.3310 \pm 670^{b}\right)$ \\
\hline $\begin{array}{l}\mathrm{BUN} \\
(\mathrm{mg} / \mathrm{dl})\end{array}$ & $12.8 \pm 1.0^{\mathrm{a})}$ & $39.5 \pm 2.8^{\mathrm{a}) \mathrm{b}}$ & $59.8 \pm 1.5^{b)}$ \\
\hline $\begin{array}{c}\text { Creatinine } \\
(\mathrm{mg} / \mathrm{dl})\end{array}$ & $0.38 \pm 0.08^{\mathrm{a}}$ & $2.15 \pm 0.14^{a) b}$ & $1.66 \pm 0.05^{\mathrm{b})}$ \\
\hline
\end{tabular}

Values are expressed as the means \pm SD for 5-6 rats.

Aspin-Welch test: Means sharing a common superscript letter are significantly different $(p<$ 0.05). a): Control group $v s$ Group treated with BSO, b): Group treated with BSO vs Group treated with BSO and GSH ester.
と同様な值を示したが，クレアチニン量および LDH 活 性はそれぞれコントロール群の 4.4, 1.5 倍で BSO 投 与群よりは低值を示した（Table 1)。

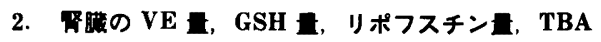
优および醅泰活性

留荿重量は BSO 投与群, GSH 投与群ともにコント ロール群に比へ增加していた(Table 2)。GSH 量は BSO 投与群ではコントロール群の約 $10 \%$ に減少した。GSH 投与群はコントロール群の約 $28 \%$ で, BSO 投与群の 2.9 倍の値を示し, GSH ester 投与による GSH 量の上 昇が認められた。VE 量はVE添加飼料 (VE $100 \mathrm{IU} /$ $\mathrm{kg}$ diet）で飼有したラットの值の 4 6\%に減少してい たが，BSO 投与あるいは GSH ester 投与に伴う変化は 観察されなかった。

VE 欠乏時に增加した過酸化脂質の指標となる TBA 值は，BSO 投与群においてコントロール群の約 $70 \%$ に 低下したか，GSH 投与群ではコントロール群と同様な 值を示した。一方, 過酸化脂質とアミ，酸等との反応で 生成するとされるリポフスチン量は，BSO 投与群では TBA 值の低下とは逆にコントロール群の 4.6 倍と急激 な上界が認められた。これに対し，GSH 投与群はコン トロール群と同程度の値を示し，GSH ester 投与による リポフスチン生成抑制が認められた。

酵素活性では, GSH-px 活性はBSO 投与群ではコント ロール群の約 70〜75\% に低下したが，GSH 投与群では 活性がコントロール群の值にほぼ近い值にまで回復して いた。GSSG-R 活性は 3 群間に差は認められなかった。 GST 活性は GSH 投与群において BSO 投与群より上昇 していた。

Table 2. Effect of GSH monoester on TBA value, lipofuscin content and enzyme activities in the kidneys of rats administered BSO.

\begin{tabular}{|c|c|c|c|}
\hline & Control & Treated with BSO & $\begin{array}{l}\text { Treated with BSO } \\
\text { and GSH ester }\end{array}$ \\
\hline Weight*1 & $2.06 \pm 0.12^{\mathrm{a})}$ & $\left.2.49 \pm 0.18^{\mathrm{a}) \mathrm{b}}\right)$ & $3.11 \pm 0.21^{b)}$ \\
\hline$\alpha$-tocopherol*2 & $\left.4.67 \pm 1.39^{a}\right)$ & $\left.6.78 \pm 2.23^{a}\right)$ & $5.96 \pm 1.76$ \\
\hline Total GSH*3 & $\left.820.9 \pm 90.9^{a}\right)$ & $\left.\left.78.7 \pm 8.8^{a}\right) b\right)$ & $228.1 \pm 55.4^{b)}$ \\
\hline $\mathrm{TBA}^{* 4}$ & $\left.0.67 \pm 0.04^{a}\right)$ & $\left.0.48 \pm 0.05^{a) b}\right)$ & $\left.0.68 \pm 0.06^{b}\right)$ \\
\hline Lipofuscin*5 & $0.18 \pm 0.04^{a)}$ & $\left.\left.0.83 \pm 0.13^{a}\right) b\right)$ & $0.20 \pm 0.05^{b)}$ \\
\hline \multirow{2}{*}{ GSH-px } & $131.8 \pm 8.8^{* 6 a)}$ & $98.3 \pm 8.8^{\mathrm{a}) \mathrm{b}}$ & $123.0 \pm 12.4^{b)}$ \\
\hline & $152.2 \pm 9.9 * 7 a)$ & $104.3 \pm 6.8^{\mathrm{a}) \mathrm{b}}$ & $130.0 \pm 13.0^{\mathrm{b})}$ \\
\hline GSSG-R*8 & $43.7 \pm 3.6$ & $42.7 \pm 5.2$ & $44.1 \pm 5.1$ \\
\hline GST*9 & $65.4 \pm 5.1$ & $60.5 \pm 9.1^{b)}$ & $\left.73.4 \pm 8.8^{b}\right)$ \\
\hline
\end{tabular}

${ }^{* 1} \mathrm{~g},{ }^{* 2} \mathrm{ng} / \mathrm{mg}$ protein, ${ }^{* 3} \mu \mathrm{g} / \mathrm{g}$ wet tissue, ${ }^{* 4} \mathrm{nmol} \mathrm{MDA} / \mathrm{mg}$ protein, ${ }^{* 5} \mu \mathrm{g}$ Quinine sulfate/g wet tissue (Ex $345 \mathrm{~nm}, \operatorname{Em} 435 \mathrm{~nm}$ ), ${ }^{* 6}$ Se-dependent GSH-px activity, nmol NADPH $/ \mathrm{min} / \mathrm{mg}$ protein, *7 Total GSH-px activity, nmol NADPH/min/mg protein, ${ }^{* 8} \mathrm{nmol} \mathrm{NADPH} / \mathrm{min} / \mathrm{mg}$ protein, ${ }^{* 9} \mathrm{nmol}$ S-conjugate transformed $/ \mathrm{min} / \mathrm{mg}$ protein.

Values are expressed as the means $\pm S D$ for 6 rats, a),b): See the footnote of Table 1. 


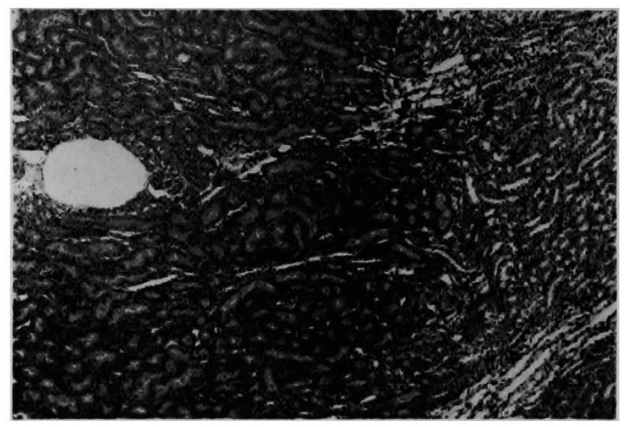

Fig. 1. Kidney of BSO-untreated rat. (H-E, $\times 16$ )

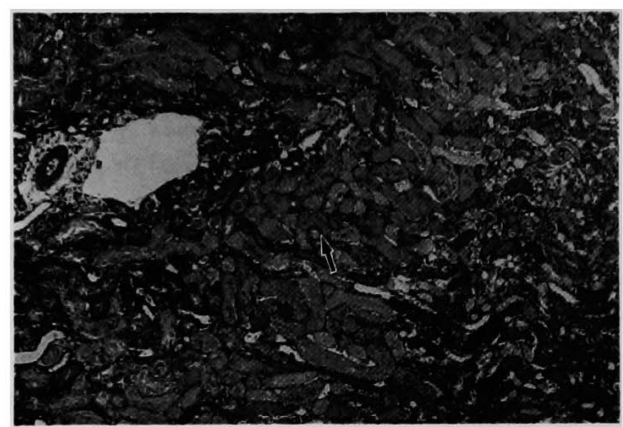

Fig. 2. Kidney of BSO-treated rat.

Necrosis of the tubular epithelium is extensively observed in the $S_{3}$ segment of the proximal tubules. $(\mathrm{H}-\mathrm{E}, \times 16)$

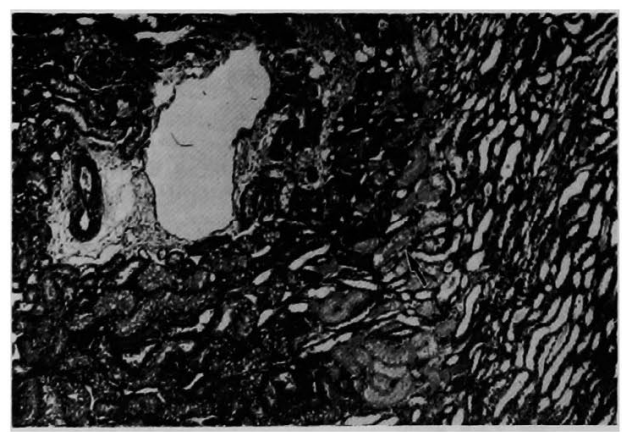

Fig. 3. Kidney of BSO- and GSH-treated rat.

Necrosis of the tubular epithelium is observed only in the $S_{3}$ segment of the proximal tubules near the descending thin limb of Henle's loop. $(\mathrm{H}-\mathrm{E}, \times 16)$

\section{3. 腎瞃の光学顕徽鏡による検索}

BSO 投与群の近位尿細管上皮細胞は近位直尿細管に 壊死，剝離が，また䯣放線（medullary ray）に沿って同
様な現象が観察されるのに対し，GSH 投与群ではへン レループの下行脚に近い部位に限定して非常に狭い範囲 に壊死が認められるのみであり，GSH ester 投与による 組織障害抑制が観察された（Fig. 1 3)。

$$
\text { 考察 }
$$

堅臓は虚血再かん流時, 酸化的ストレスに伴いGSH 量の減少による腎機能障害が認められる。それゆえこの 障害の発症と GSH とが関連していることが知られてい る28)29)。しかし，その発症機序や GSH の防御機構につ いては未だ明らかではない。

先に筆者らは，VE 欠乏 GSH 低下による腎瓵障害の 経日的検討を行い,VE 欠乏時に生成した過酸化脂質は BSO 投与による GSH の低下に伴い経日的に減少し, BSO 投与 3 日目ではコントロール群の半分に減少して いたのに対し，過酸化脂質とアミ，酸等との反応で生成 するとされるリポフスチンは，BSO 投与 1 日目から增 加し，2 日目では6 倍に達することを見いたし ${ }^{15)}$ ，VE 欠乏時に増加していた過酸化脂質のらち TBA 值の減少 した部分はリポフスチン生成に関与することを示唆し た。一方，GSH の低下がないときにはりポフスチンの 大幅な生成が認められないことから，GSH はりポフス チンの生成抑制に寄与していると考えられることを報告 した ${ }^{14) 15) 。 ~}$

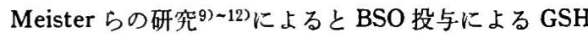
低下を伴ら組織障害は GSH ester 誘導体を投与するこ とで防御できるとしている。

筆者らは先に, VE 欠乏ラットにBSO を投与し GSH 低下に伴ら腎葴障害に対 L, GSH monoisopropyl ester (GSH ester) を投与し, 過酸化脂質からのリポフスチン 生成抑制への GSH の関与, さらに腎機能低下や腎障害 発症に関寸る GSH の防御効果について検討したか， GSH ester 投与に书いても近位直尿細管上皮細胞に広く 壊死が認められ，障害を完全には防御寸ることはできな いことを報告した16)。

そこで今回，この近位尿細管上皮細胞壊死を伴う腎臓 障害において，この障害の程度を軽微にした上で $\mathrm{GSH}$ の防御効果を観察する目的で，BSO の投与回数を減ら L，さらに GSH ester の投与回数および投与時期を変 更して，腎臓機能低下および組織障害に対する GSH ester の投与効果を検討した。腎臓中の GSH 量は BSO 投与群と比較し、GSH 投与群においてその量に增加が 認められた。BSO 投与群の TBA 值はコントロール群 に比し低下を示したのに対し，GSH 投与群のそれは BSO 投与群より高値でコントロール群とほぼ同值を示 した。一方、リポフスチン㽬は BSO 投与群で急激な上 异が観察されたのに対し，GSH 投与群のそれはコント 
ロール群とほぼ同值を示した。祭䐵中の GSH 1 量が GSH 投与群においてその贯に增加が諗められたことと考え合 わせ, 過酸化脂筫からのリポフスチンの生成抑制に GSH が強く関与していることが示唆された。

睛機能を示すクレフチニン吾は BSO 投与群でコント ロール群の 5.7 倍の值を示したのに対し，GSH 投与群 では 4.4 倍を示し, GSH ester 投与による機能の回復 が認められた。GSH 投与群の BUN 量は BSO 投与群 と同様高值を示し，クレアチニン最の変化と類似した変

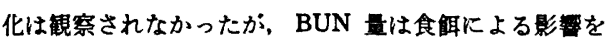
受けやすいことから、GSH 投与群が高値を示したのは 投与した GSH ester による GSH 量の增加によるるの と思われる。BSO 投与によるクレアチニン量と BUN 量 の増加は近位尿細管上皮細胞の膨化や壊死飞伴 5 尿細管 内压力の增加による糸球体減過率の低下に起因すると考 えられる。リポフスチン生成が抑制された GSH 投与群 の LDH 活性は BSO 投与群の約半分の值を示した。 LDH 活性の上䄯が完全には抑制されず，半分の值ま でしか低下できなかったことは，光学顕微鏡による検索 です明らかなように GSH ester 投与によっても近位尿 細管上皮細胞壊死は完全には抑制されておらず, 近位直 尿細管の非常に限定された部位ではあるが，上皮細胞に 変性が認められたことによるるのと思われる。

LDH 活性以外の醉素活性に関しては, BSO 投与で低 下した GSH-px 活性は GSH ester 投与によってほぼ完 全に回復し, GSH の効果が認められた。GSSG-R 活性 および GST 活性は3群間でほとんど差は認められな かった。

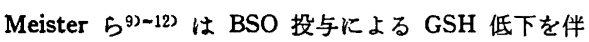
万組織障害は GSH ester 誘導体を投与することで防御 できるとしているか，脂質過酸化あるいは GSH の抗酸 化作用等には言及していない。腎缄の尿細管上皮細胞中 には高浱度の GSH が存在 ${ }^{30}$ することから，たんに GSH 低下による組織障害とすれば GSH ester 投与により防 御できると考えられる。しかし，本研究で惹起したVE 欠乏 GSH 低下による堅臟障害において, GSH ester 投 与により堅缄内リポフスチン生成抑制, 血清クレアチニ ン量の上昇抑制, また骨臟内酵素活性の回復が認められ たものの，堅䁍機能や組織障害を完全には抑制あるいは 防御することはできなかった。その理由として，BSO 投与による堅险内 GSH 量の低下が著しいことや GSH ester 投与による觜 GSH 量の增加, さらに形態学的に みた回復の程度などから考えると, 赑葴の部位により GSH の必要量が異なるためであることが推測される。

Okada らは，鉄ニトリロ三酢酸（Fe-NTA）をラット に腹腔内投与すると投与初期には強い近位尿細管壊死が 起こり，長期投与で堅满に高率に腺がんを発生じ1，
VE はこの督荿における脂質過酸化を阻止し, 組織学的

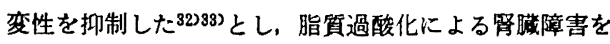
報告している。筆者らがこれまでに行った本督臓障害に おいても，GSH の低下に伴い，VE 欠乏時に生成してい た過酸化脂質と細胞内成分，あるいは細胞膜を構成する タンパク質などとの反応によるリポフスチンの大量生成 とそれによる堅機能障害, さらに続いて細胞崩壊が起こ り，堅障害の增大が進行すると推測され(5)，脂質過酸化 がこの障害を惹起すると考えられた。また，BSO 投与 と同時に GSH ester を投与することにより近位尿細管 上皮細胞壊死が若干抑制できたことから，GSH はこの 過酸化脂質からのリポフスチン生成の抑制，さらには堅 機能低下や組織障害の防御に強く関与している可能性を 示唆し16)，今回，これまでよりも障害の程度を軽微に し，より緩和な条件下で GSH の防御効果を観察した。 その結果, GSH ester の投与により完全な防御は認めら れなかったものの, 近位直尿細管上皮細胞の中でも非常 に狭い範囲にのみ限定して壊死が観察される程度に障害

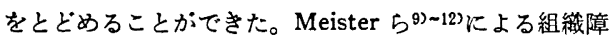
害の GSH ester 誘導体投与による防御と結果を異にす ることに関しては，GSH の投与量，投与方法，投与時 期あるいは生体外からの GSH 投与の有効性など種々考 えられるが, 彼らの組織とは違い腎葴であること，また VE 欠乏により過酸化脂質の生成が高まった条件下での 腎蔵障害である点に大きな连いがあるように思われる。 今後,さらに r-glutamylcysteine 投与による内因性 GSH の効果や他の抗酸化剂の影響などを検討しこの堅缄障 害の防御について研究する必要がある。

$$
\text { 要 約 }
$$

VE 欠乏ラットの GSH 低下による腎臓障害に対する GSH monoisopropyl ester の投与効果を明らかにするた

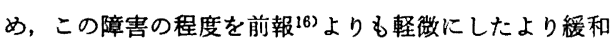
な条件下でリボフスチン生成および腎荿機能や組織障害 を指標に検討を行った。

1） GSH ester 投与は腎臓内 GSH 量を增加させ，リ ポフスチン量の急激な上昇を抑制した。

2) GSH ester 投与は血清クレアチニン量の增加, 腎 臓内䤃素活性の低下を抑制した。

3） GSH ester 投与は近位尿細管上皮細胞壇死を完全 には防御することはできなかったか，近位直尿細管上皮 細胞のらちへンレループの下行脚に近い部位に限定して 非常に狭い範囲にのみ壊死が観察できる程度にとどめる ことができた。

4）GSH は過酸化脂質からのリポフスチン生成を抑 制し, 腎機能低下や堅障害の防御に関与する可能性が強 く示唆された。 
実験に際し GSH monoisopropyl ester をご供与くだ さいました山之内製薬(株)に感謝いたします。

\section{文献}

1) Tinberg, H.M. and Baker, A.A.: J. Nutr., 100, 413 (1970)

2) Fukuzawa, K., Chida, H., Tokumura, A. and Tsukatani, H. : Arch. Biochem. Biophys., 206, 173 (1981)

3) Ohki, K., Takamura, T. and Nozawa, Y.: J. Nutr. Sci. Vitaminol., 30, 221 (1984)

4) Tappel, A.L. : Ann. N.Y. Acad. Sci., 203, 12 (1972)

5) Burk, R.F. : Biochim. Biophys. Acta, 757, 21 (1983)

6) Haenen, G.R.M.M. and Bast, A. : FEBS Lett., 159,24 (1983)

7) Hishinuma, I. and Nakamura, T. : J. Nutr. Sci. Vitaminol., 34, 11 (1988)

8) György, P. and Goldbaltt, H. : J. Exp. Med., 89, 245 (1949)

9) Mårtensson, J. and Meister, A. : Proc. Natl. Acad. Sci. USA, 86, 471 (1989)

10) Mårtensson, J., Jain, A., Frayer, W. and Meister, A. : Proc. Natl. Acad. Sci. USA, 86, 5296 (1989)

11) Mårtensson, J., Jain, A. and Meister, A.: Proc. Natl. Acad. Sci. USA, 87, 1715 (1990)

12) Mårtensson, J., Steinherz, R., Jain, A. and Meister, A. : Proc. Natl. Acad. Sci. USA, 86, 8727 (1989)

13）辇原清和, 津田明子, 市川富夫 : 栄食誌, 42, 377 (1989)

14) Hagiwara, K., Naitou, K., Kurokawa, Y. and Ichikawa, T. : J. Nutr. Sci. Vitaminol., 37, 99 (1991)

15）䔉原清和, 岡純, 小篠 栄, 市川富夫：栄食 誌, 44, 391 (1991)

16) 萩原清和, 岡純, 小簙 栄, 市川富夫 : 栄食
誌, 45, 55 (1992)

17) 毛利佳世, 道本千衣子, 活州はるみ, 五十嵐修 : 栄食誌，36, 122 (1983)

18) Bieri, J.G., Stoewsand, G.S., Briggs, G.M., Phillips, R.W., Woodard, J.C. and Knapka, J.J. : J. Nutr., 107, 1340 (1977)

19）池畑秀夫，杉山嘉子：ビタミン，37，31（1968）

20）石橋恭子, 阿部皓一, 大前雅彦, 阿部 站, 勝井 五一郎：ビタミン, 51，415（1977）

21) Buege, J.A. and Aust, S.D. : Methods in Enzymology (Fleischer, S. and Packer, L., eds.), 302 (1978), Academic Press (New York)

22) Fletcher, B.L., Dillard, C.J. and Tappel, A.L. : Anal. Biochem., 52, 1 (1973)

23) Tietze, F. : Anal. Biochem., 27, 502 (1969)

24) Lawrence, R.A. and Burk, R.F. : Biochem. Biophys. Res. Commun., 71, 952 (1976)

25) Xia, Y., Hill, K.E. and Burk, R.F. : J. Nutr. 115, 733 (1985)

26) Habig, W.H., Pabst, M.J. and Jakoby, W.B. : J. Biol. Chem., 22, 7130 (1974)

27) Lowry, O.H., Rosebrough, N.J., Farr, A.L and Randall, R.J. : J. Biol. Chem., 193, 265 (1951)

28) Paller, M.S. : Kidney Int., 33, 843 (1988)

29) McCoy, R.N., Hill, K.E., Ayon, M.A., Stein, J.H. and Burk, R.F. : Kidney Int., 33, 812 (1988)

30) Brehe, J.E., Chan, A.W.K., Alvey, T.R. and Burke, H.B. : Am. J. Physiol., 231, 1536 (1976)

31) Hamazaki, S., Okada, S., Ebina, Y., Fujioka, M. and Midorikawa, O. : Am.J. Pathol., 123, 343 (1986)

32) Okada, S., Hamazaki, S., Ebina, Y., Li, J.L. and Midorikawa, O.: Biochim. Biophys. Acta, 922, 28 (1987)

33) Hamazaki, S., Okada, S., Ebina, Y., Li, J.L. and Midorikawa, O.: Toxicol. Appl. Pharmacol., 92, 500 (1988)

（1992 年 1 月 14 日受理） 